TEKNIK, 40 (3), 2019, 176-183

\title{
Rancang Bangun Alat Terapi Lengan Continous Passive Motion (CPM) dengan Control Electromyograph (EMG) Untuk Pasien Pasca Operasi dan Stroke
}

\author{
Fajar Setiono*, Faqih Rofii, Sabar Setiawidayat \\ Jurusan Teknik Elektro, Universitas Widyagama Malang, \\ Kampus III, Jl. Taman Borobudur Indah No. 3 Malang, Indonesia 65142
}

\begin{abstract}
Abstrak
Peralatan kesehatan bidang fisiotherapy mengalami banyak perkembangan, diantaranya untuk pemulihan pasien pasca operasi patah tulang dan stroke. Pasien membutuhkan alat bantu perangkat Continous Passive Motion (CPM) untuk gerakan pasif terus menerus yang berfungsi melatih kinerja lengan dan kaki untuk pemulihan kekakuan gerakan. Perangkat CPM yang ada masih menggunakan sistem analog dan tidak ada sistem monitoring kondisi pasien. Penelitian ini menggabungkan perangkat Continuous Passive Motion (CPM) lengan dengan Control Electromyograph (EMG) untuk mengoptimalkan proses pemulihan pasien pasca operasi dan stroke. Rotary Encoder dan rangkaian Pulse Width Modulation memonitoring pasien secara kontinu. Hasil kalibrasi sistem driver motor pada kecepatan motor adalah 68.7 rpm dan sudut posisi motor adalah $44.8^{\circ}$ dengan batas nilai toleransi masing-masing $\pm 5 \%$ sedang pembacaan sensor sinyal EMG terukur nilai amplitude rata-rata sebesar $0,242 \mathrm{mV}$ pada sinyal gerak lengan $45^{\circ}$ dan $0,253 \mathrm{mV}$ pada sinyal gerak lengan $90^{\circ}$.
\end{abstract}

Kata kunci: electromyograph; CPM; rotary encoder; pulse width modulation; motor DC

\begin{abstract}
[Title: Design of Continous Passive Motion (CPM) Arm Therapy Tool with Electromyograph (EMG) Control for Post surgery and Stroke Patients] The health equipment in the field of physiotherapy has developed. Among them for the recovery of patients after surgery fractures and strokes. Patients need a Continous Passive Motion (CPM) device for continuous passive movement that functions to train the performance of the arms and legs to recover stiffness of movement. The existing CPM device still uses an analog system and there is no patient condition monitoring system. This study combines the arm's CPM device with Electromyograph (EMG) control to optimize the recovery process of patients postoperatively and stroke. The Rotary Encoder and Pulse Width Modulation circuit monitor the patient continuously. The results of the calibration of the motor driver system at motor speed is 68.7 rpm and the motor position angle is $44.8^{\circ}$ with a tolerance value of $\pm 5 \%$ while the EMG signal sensor readings measured the average amplitude value of $0.242 \mathrm{mV}$ on the $45^{\circ}$ and $0.253 \mathrm{mV}$ arm motion signals at the $90^{\circ}$ arm motion signal, respectively.
\end{abstract}

Keywords: electromyograph; CPM; rotary encoder; pulse width modulation; DC motor

\section{Pendahuluan}

Terapi adalah pemulihan kesehatan seseorang karena suatu penyakit akibat cidera, yang berfungsi untuk mengembalikan fungsi tubuh seperti semula. Prinsip kerja alat terapi yaitu ada yang memancarkan

\footnotetext{
*) Penulis Korespondensi.

E-mail: fajar_268@yahoo.co.id
}

sinar, memancarkan frekuensi tinggi dan menggerakan bagian tubuh sebagai alat bantu melatih bergerak (Ho \& Chen, 2006).

Pada penelitian ini, akan memanfaatkan terapi dengan menggerakkan bagian tubuh sebagai alat bantu melatih bergerak, khususnya terapi untuk pergerakan tangan dan sendi siku pada orang pasca cidera patah tulang (O’Driscoll \& Giori, 2000). Proses penyembuhan cidera 


\section{TEKNIK, 40 (3), 2019, 177}

patah tulang harus melewati masa rehabilitasi. Pemulihan berbagai gerak sendi setelah operasi atau trauma tergantung pada rehabilitasi. Keterlambatan rehabilitasi selanjutnya dapat mengakibatkan fungsi sendi yang buruk atau imobilitas.

Rehabilitasi melibatkan terapi dari sendi menggunakan latihan aktif untuk mengembalikan kekuatan dan gerakan pasif untuk mengembalikan mobilitas. Gerakan pasif dapat dibantu oleh fisioterapi yaitu Continuous Passive Motion (CPM) (O’Driscoll \& Giori, 2000; Saputra, Wardana, \& Rokhana, 2010). CPM adalah gerakan pasif yang terus menerus berfungsi melatih kinerja lengan dan siku, CPM efektif dalam pemulihan kekakuan gerakan penuh yang diterapkan setelah operasi dan pemulihan sakit stroke (Nugraha, 2010).

Kehilangan atau berkurangnya gerakan di lengan dapat mengurangi kualitas hidup seseorang, untuk memulihkan kemampuan gerak para pasien awalnya di arahkan untuk mendapatkan perawatan non bedah seperti olahraga atau fisioterapi (Ho \& Chen, 2006; Umchid \& Taraphongphan, 2016).

Otot adalah sebuah jaringan konektif dalam tubuh yang tugas utamanya kontraksi. Kontraksi otot berfungsi untuk memindahkan /menggerakkan bagian-bagian tubuh \& substansi dalam tubuh. Ada tiga macam sel otot dalam tubuh manusia (jantung, lurik dan polos) namun yang berperan dalam pergerakan kerangka tubuh manusia adalah otot lurik (otot rangka) (Nugraha, 2010; O’Driscoll \& Giori, 2000).

Otot rangka adalah jaringan peka rangsang yang diatur oleh saraf motorik somatic dalam kesatuan yang disebut syaraf motorik unit (Rokhana, 2009). Sinyal otot nantinya akan disadap menggunakan elektroda dan diolah menggunakan EMG (Saputra, Wardana, \& Rokhana, 2010)

Dari ke enam referensi yang peneliti ambil berisi tentang EMG dan CPM. Didalam referensi EMG, sinyal EMG hanya diaplikasikan ke mekanik robot saja dengan berbagai metode, sedangkan didalam referensi CPM hanya menjelaskan kinerja gerak CPM dan pemulihan stuktur otot serta sendi lengan siku. Berdasarkan referensi diatas belum ada yang menggabungkan kinerja alat EMG dan CPM, oleh sebab penelitian ini bertujuan untuk merancang alat terapi lengan Continous Pasive Motion (CPM) dengan sinyal Electromyograph (EMG).

Alat Continuous Passive Motion (CPM) digunakan selama fase awal dari rehabilitasi, setelah bedah atau trauma pada persendian. Alat CPM menggerakan sendi secara terus menerus dan berulangulang pada jarak yang terkontrol.

Penggunaan setiap hari meningkatkan pergerakan sendi yang semula terbatas dan digunakan untuk mencegah efek negatif dari imobilisasi sendi seperti kekakuan sendi, pembengkakan, artikulasi kartilago yang buruk kekurangan gizi, kehilangan kolagen atau penyakit tromboemboli.
Terapi ini memastikan dilakukan latihan yang aman selama penyembuhan dan fase perbaikan jaringan dengan memungkinkan pergerakan pasif, mengurangi nyeri pasca operasi dan meminimalkan peluang terjadinya inflamasi. CPM juga membantu meningkatkan jarak pergerakan dan memiliki efek yang baik pada kekuatan otot. CPM menstimulasi metabolisme kondrosit, yang penting untuk proses regenerasi sendi. Menggunakan lead CPM untuk mengurangi jumlah obat yang dikonsumsi, keluar lebih cepat dari rumah sakit, mengurangi perawatan pasien paca keluar dari rumah sakit dan biaya yang lebih rendah untuk sistem perawatan kesehatan.

\section{Bahan dan Metode}

\subsection{Blok Diagram Secara Umum Sistem}

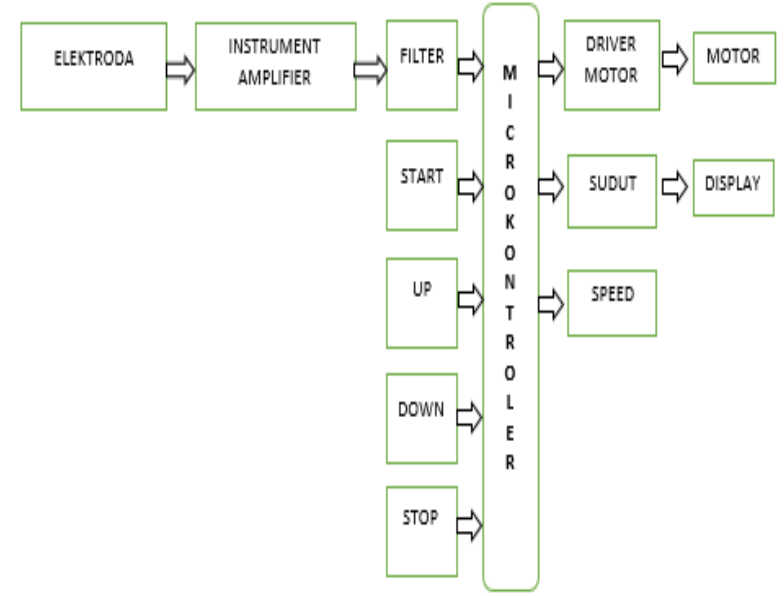

Gambar 1. Blok diagram system alat

Pada Gambar 1, sinyal otot disadap menggunakan teknik dua elektroda utama dan satu elektroda ground yang diletakkan pada permukaan kulit bagian lengan seperti ditunjukkan pada Gambar 2. Sadapan sinyal otot akan diteruskan ke rangkaian instrument amplifier untuk mendapatkan penguatan.

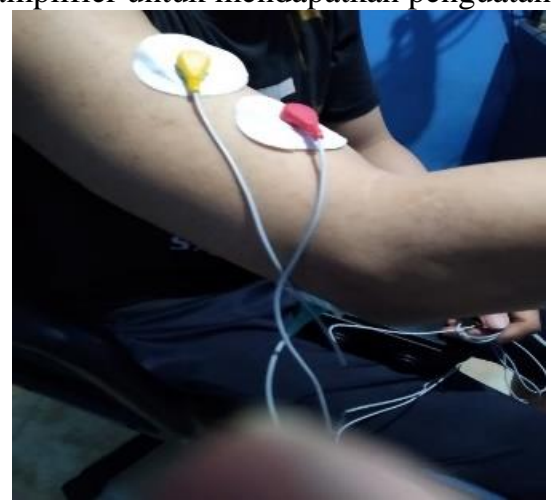

Gambar 2. Posisi elektrode pada otot lengan 


\section{TEKNIK, 40 (3), 2019, 178}

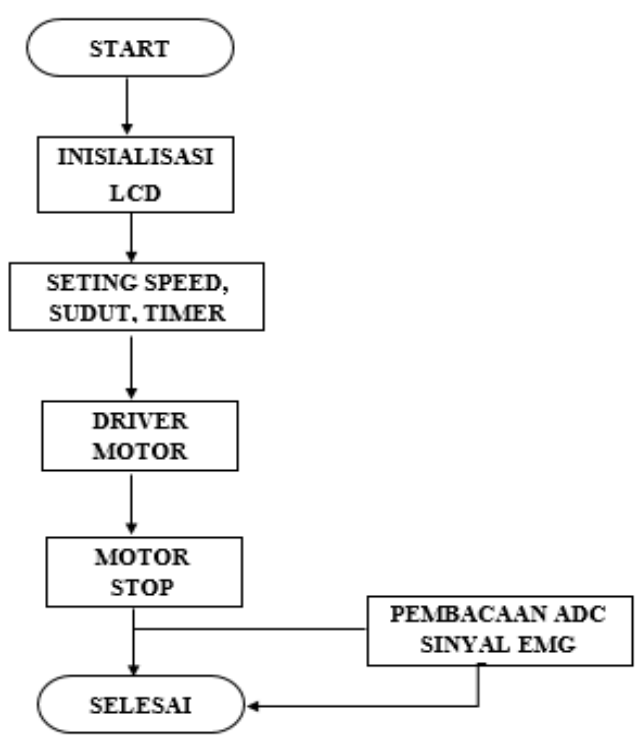

Gambar 3. Diagram alir proses program

Sinyal keluaran dari instrumentasi amplifier didapat dari beda potensial sinyal otot tubuh yang ditangkap oleh elektroda yang berada dalam range $0,5-$ $5 \mathrm{mV}$ dan dalam frekuensi $0,5-1000 \mathrm{~Hz}$. Rangkaian instrumentation amplifier ini mengunakan $\mathrm{R}$ Gain sebesar $10 \mathrm{~K} \Omega$ dengan penguatan sebesar 5,94 kali. Kemudian keluaran sinyal dari penguat akan masuk ke rangkaian Low Pass Filter (LPF) dengan frekuensi cut off sebesar $589,76 \mathrm{~Hz}$, yang memiliki nilai Penguat loop tertutup (ACL) yang berbeda-beda sesuai frekuensi input. Semakin kecil frekuensi maka akan semakin besar ACL nya. Setelah melewati LPF, maka sinyal akan masuk ke High Pass Filter (HPF) dengan frekuensi cut off sebesar $48,25 \mathrm{~Hz}$ yang merupakan filter yang meloloskan frekuensi tinggi di atas frekuensi cut off dan meredam frekuensi rendah di bawah frekuensi cut off. Sinyal otot tersebut dimasukan ke mikrokontroler sebagai input pengolahan data dengan tampilan nilai sinyal EMG didisplay yang bertujuan untuk memonitoring kondisi sinyal EMG pada otot lengan. Output dari mikrokontroler akan mengatur kinerja driver motor yang berfungsi untuk menggerakkan motor dengan mengatur nilai seting kecepatan dan posisi sudut motor.

\subsection{Bahan}

a. Sensor EMG

Sensor EMG yang terdiri dari rangkaian penguat Op-Amp Rangkaian sensor ini berfungsi untuk menyadap sinyal EMG. Rangkaian ini menggunakan IC instrument AD8266, di dalam IC ini terdapat tiga opamp yang berfungsi sebagai non inverting amplifier, inverting amplifier dan differensial amplifier(Muscle sensor V3 user manual, 2013).

\section{b. Rangkaian Driver Motor DC}

Rangkaian driver motor yang terdiri dari pengatur kecepatan putar motor dan pengatur posisi sudut putaran motor. Pada pengaturan kecepatan putar motor pulsa PWM digunakan dalam mengatur tegangan, tegangan beban diatur dangan cara mengatur duty cycle dari gelombang kotak yang disupplykan ke basis dari transistor. Duty cycle adalah persentase besar siklus aktif didalam satu frekuensi pita tegangan (Nainggolan, Rusdinar, \& Sunarya, 2015). Untuk mengukur duty cycle dapat menggunakan rumus Persamaan 1.

$$
\text { Duty cycle }=\frac{\text { siklus aktif }}{\text { siklus total }} \times 100 \%
$$

Pengaturan posisi sudut motor dc mengunakan menggunakan sensor rotary encoder yang terdiri dari komponen berupa piringan mika dan optocoupler. Dimana pada rangkaian ini optocoupler digunakan untuk mendapatkan frekuensi on/off dari putaran sensor yang di hubungkan dengan poros motor DC. Optocoupler yang digunakan adalah optocoupler dengan model U. optocoupler ini diletakan di antara sisi piringan mika yang terdapat lubang- lubang sebanyak 100 lubang yang berfungsi untuk melewatkan cahaya dari sinar LED menuju sensor optocoupler (Rajestari, Feizi \& Taghvaei, 2017).

Komponen ini merupakan kombinasi infra merah dan photodiode sebagai pemancar dan penerima cahaya. (Belo, Rofii \& Qustoniah, 2018)

\section{c. Mikrokontroler}

Rangkaian mikrokontroler digunakan untuk mengontrol sistem kerja alat dengan pemprograman yang telah dibuat dan mengolah data dan mengatur pergerakan motor baik putaran naik atau turun untuk selanjutnya ditampilkan didisplay LCD ( Belo, Rofii \& Qustoniah, 2018; Rattarojpan \& Umchid, 2012., Setiawidayat \& Jogijantoro, 2018).

\section{d. LCD}

LCD digunakan untuk menampilkan nilai seting yang diinginkan dan monitoring sinyal EMG. (Rattarojpan \& Umchid, 2012).

\section{e. Gerakan CPM}

Kebutuhan data tentang waktu proses therapi gerakan CPM di gunakan sebagai informasi dan pendukung untuk analisis data selanjutnya (Nugraha, 2010). Sudut terapi menyesuaikan dengan kondisi pasien, seperti ditunjukkan pada Gambar 4. 


\section{TEKNIK, 40 (3), 2019, 179}

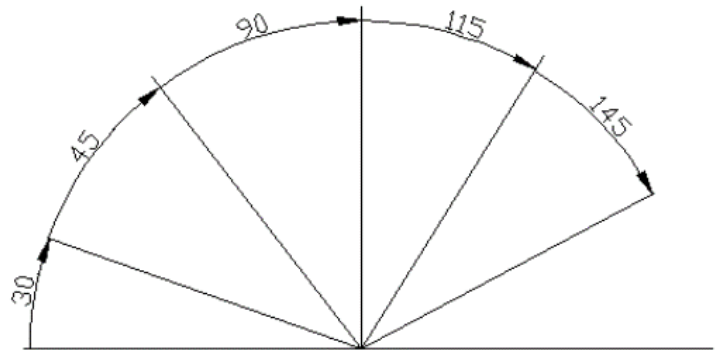

Gambar 4. Sudut gerakan siku lengan

Tabel 1. Tahap proses terapi siku lengan (Zhao, 2018).

\begin{tabular}{ccc}
\hline Masa Therapi & $\begin{array}{c}\text { Sudut } \\
\text { gerakan } \\
\text { siku }\end{array}$ & Waktu \\
\hline 1-2 Minggu & $30^{\circ}$ & 45 menit/hari \\
2-4 Minggu & $45^{\circ}$ & $15-20$ menit/hari \\
4-8 Minggu & $90^{\circ}$ & $15-20$ menit/hari \\
\hline
\end{tabular}

\subsection{Perancangan Alat}

Setelah membuat modul maka perlu diadakan pengujian dan pengukuran. Agar dapat diketahui seberapa tepat pembuatan alat ini, maka penulis melakukan pendataan melalui pengukuran dan pengujian. Tujuannya adalah untuk mengetahui apakah masing-masing komponen dapat berfungsi sesuai dengan yang direncanakan.

Rangkaian sensor EMG yang terdiri dari rangkaian Penguat Op Amp, ditunjukkan pada Gambar 5.

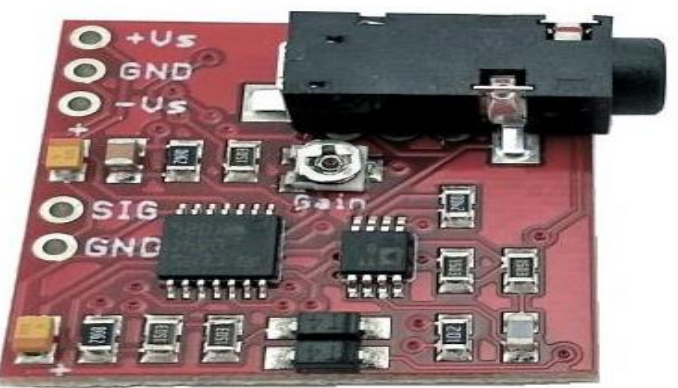

Gambar 5. Rangkaian sensor EMG

Perancangan driver motor yang terdiri dari pengatur kecepatan putar motor dan pengatur posisi sudut putaran motor, ditunjukkan pada Gambar 6.

Dalam rangkaian pengatur posisi sudut putaran motor ini menggunakan sensor rotary encoder yang terdiri dari komponen berupa piringan mika dan optocoupler. Pada rangkaian ini optocoupler di gunakan untuk mendapatkan frekuensi on/off dari putaran sensor yang dihubungkan dengan poros motor DC.

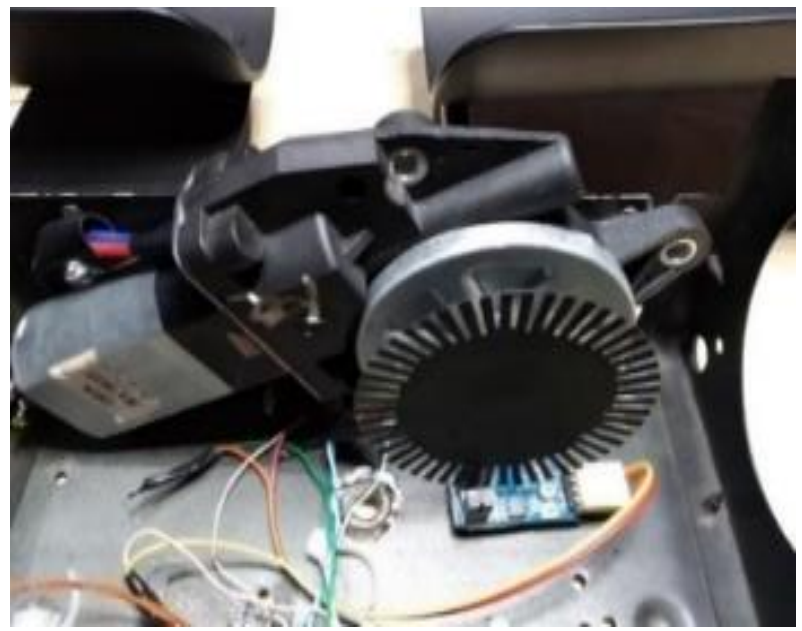

Gambar 6. Hasil perancangan sensor rotary encoder

\section{Hasil dan Pembahasan}

Hasil rancangan keseluruhan alat ditunjukkan pada Gambar 7, dimana control box ditunjukkan nomor satu, penyangga lengan nomor dua, kabel elektrode nomer tiga dan trolley nomor empat.

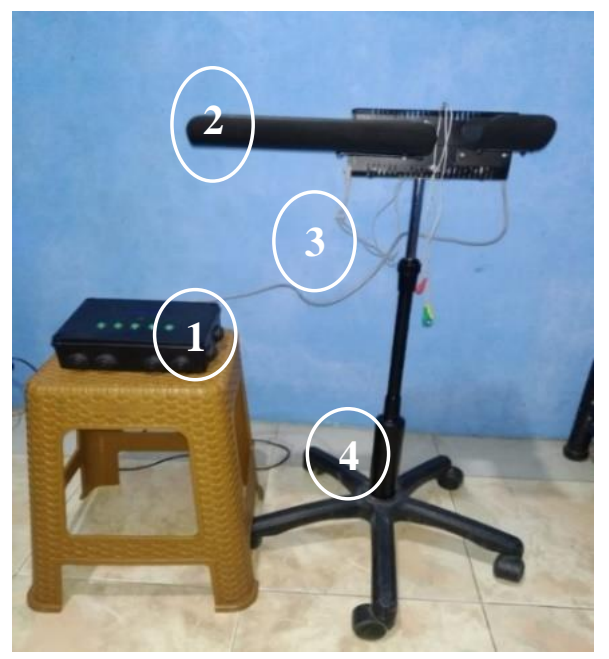

Gambar 7. Hasil perancangan alat teraphy siku/ lengan Continuous Passive Motion (CPM) dengan sinyal input electromyograph (EMG).

Metode penelitian dalam pembuatan alat ini adalah pre-experimental dengan menggunakan jenis one group pre-post test design yaitu peneliti hanya menggunakan satu kelompok subjek serta melakukan pengukuran sebelum dan sesudah pemberian perlakuan pada subjek. Perbedaan kedua hasil pengukuran tersebut dianggap sebagai efek perlawanan. Model penelitian eksperimen ini ditunjukkan pada Gambar 8. 


\section{TEKNIK, 40 (3), 2019, 180}

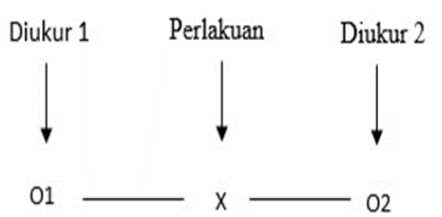

Gambar 8. Model Penelitian Eksperimen yang dilakukan

Pada Gambar 8, X adalah treatment/perlakuan yg diberikan (variabel Independen); 01 adalah observasi pertama (variabel dependen); dan 02 adalah observasi kedua (variabel dependen).

\subsection{Hasil Pengujian Sistem}

Pengujian alat ini di lakukan pada tiap bagian penting rangkaian alat, seperti ditunjukkan pada Gambar 9.

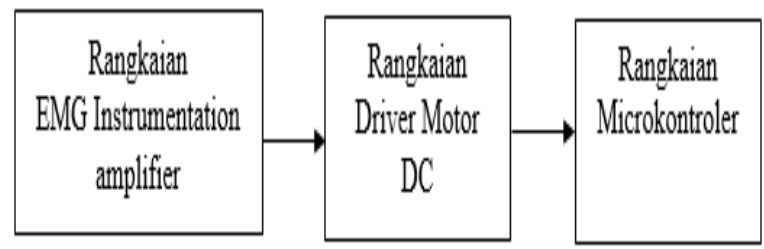

Gambar 9. Blok pengujian sistem yang dilakukan.

Rangkaian instrumen amplifier pada Gambar 9 menggunakan IC instrument AD8266, berfungsi untuk menyadap sinyal EMG.

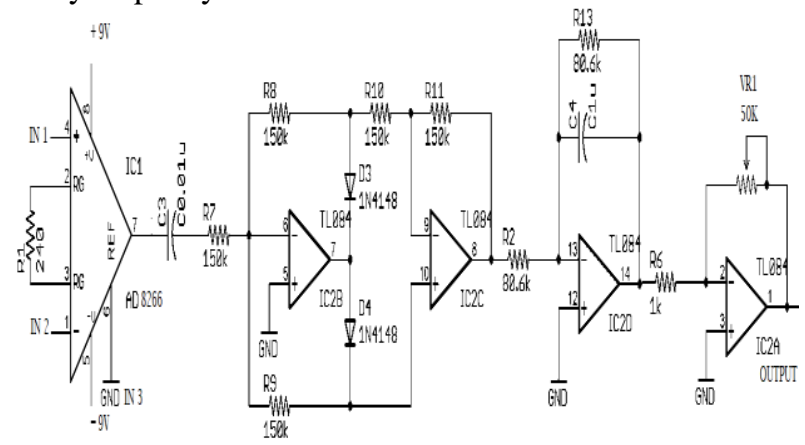

Gambar 10. Skematik rangkaian instrumen amplifier

Langkah-langkah dalam pengujian pengukuran yaitu: (1) menghubungkan VCC dan ground ke rangkaian modul EMG; (2) menghubungkan probe osiloskop ke test point output instrument; (3) mengukur tegangan output yang dihasilkan pada osiloskop; dan (4) mencatat hasilnya dan membandingkan dengan hasil perhitungan

Pengujian dilakukan dengan 6 kali ulangan pada 5 responden untuk diukur sinyal EMG menggunakan alat terapi lengan CPM dengan sinyal elektromyograph dan alat ukur oscilloscope. Hasil pengukuran ditunjukkan pada tabel 2 .
Tabel 2. Hasil pengukuran EMG instrumen amplifier

\begin{tabular}{llcccccccc}
\multirow{2}{*}{ NAMA } & \multirow{2}{*}{ KONTRAKSI } & \multicolumn{6}{c}{ HASIL PENGUKURAN } & RATA- \\
\cline { 3 - 7 } & & & II & III & IV & V & VI & $\begin{array}{c}\text { RATA } \\
\text { (V) }\end{array}$ \\
\hline Responden 1 & Rilex & 0,4 & 0,3 & 0,2 & 0,2 & 0,2 & 0,2 & 0,3 \\
Usia 23 tahun & Lemah & 0,6 & 0,5 & 0,4 & 0,4 & 0,4 & 0,4 & 0,5 \\
Berat & Kuat & 1 & 0,8 & 0,6 & 0,6 & 1 & 0,6 & 0,8 \\
Responden 2 & Rilex & 0,1 & 0,1 & 0,1 & 0,1 & 0,1 & 0,1 & 0,1 \\
Usia 25 th & Lemah & 0,4 & 0,6 & 0,4 & 0,4 & 0,4 & 0,4 & 0,4 \\
Berat 55 kg & Kuat & 1,2 & 1,4 & 1 & 1 & 1 & 0,8 & 1,1 \\
Responden 3 & Rilex & 0,3 & 0,3 & 0,3 & 0,3 & 0,3 & 0,3 & 0,3 \\
Usia 30 th & Lemah & 0,4 & 0,5 & 0,5 & 0,5 & 0,6 & 0,6 & 0,5 \\
Berat 60 kg & Kuat & 1 & 1 & 1 & 1,2 & 1,2 & 1,2 & 1,1 \\
Responden 4 & Rilex & 0,2 & 0,2 & 0,3 & 0,3 & 0,3 & 0,3 & 0,3 \\
Usia 27 th & Lemah & 0,3 & 0,3 & 0,4 & 0,4 & 0,4 & 0,4 & 0,4 \\
Berat 47 kg & Kuat & 0,6 & 0,6 & 0,6 & 0,6 & 0,6 & 0,6 & 0,6 \\
Responden 5 5 & Rilex & 0,4 & 0,3 & 0,2 & 0,2 & 0,2 & 0,3 & 0,2 \\
Usia 24 th & Lemah & 0,6 & 0,5 & 0,6 & 0,8 & 0,7 & 0,7 & 0,7 \\
Berat 60 kg & Kuat & 0,4 & 0,8 & 1 & 1 & 1,2 & 1 & 1,0 \\
\hline
\end{tabular}

Memperhatikan data pada Tabel 2, nilai rata-rata akan menjadi titik acuan untuk membuat range pengkategorian sinyal. Sinyal lemah adalah sinyal yang memiliki tegangan 0-0,2 V. Sinyal sedang adalah sinyal yang memiliki tegangan 0,3-0,5 V. Sinyal kuat adalah sinyal yang memiliki tegangan 0,6-0,92 V. Hasil pengukuran setiap responden berbeda-beda hal tersebut dikarenakan nilai beda potensial tubuh setiap orang berbeda-beda

Hasil pengukuran tegangan output instrumen dengan menggunakan oscilloscope pada kondisi kontraksi otot lemah dengan posisi sudut lengan $45^{\circ}$ mengepal kuat ditunjukkan seperti pada gambar 11 . Kondisi kontraksi otot kuat dengan posisi sudut lengan $90^{\circ}$ mengepal kuat hasil pengukuran seperti pada Gambar 12.

Hasil pengujian kecepatan putar motor ditunjukkan pada Tabel 3 dan hasil pengujian sudut posisi motor di tunjukan pada Tabel 4, yang menggunakan 10 responden. Pengujian dilakukan dengan mengatur kecepatan putaran (set point) motor dan mengatur sudut motor yang diinginkan kemudian ditampilkan di LCD dan membandingkannya dengan alat ukur. Pada pengujian pengaturan kecepatan putaran motor yang menggunakan Pulse Width Modulation (PWM) maka dilakukan pengujian dengan mengunakan alat ukur tachometer.

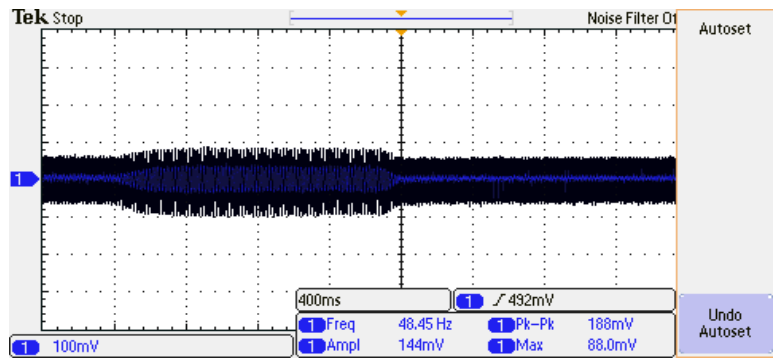

Gambar 11. Sinyal EMG keluaran dari otot kontraksi lemah dengan sudut lengan $45^{\circ}$ 


\section{TEKNIK, 40 (3), 2019, 181}

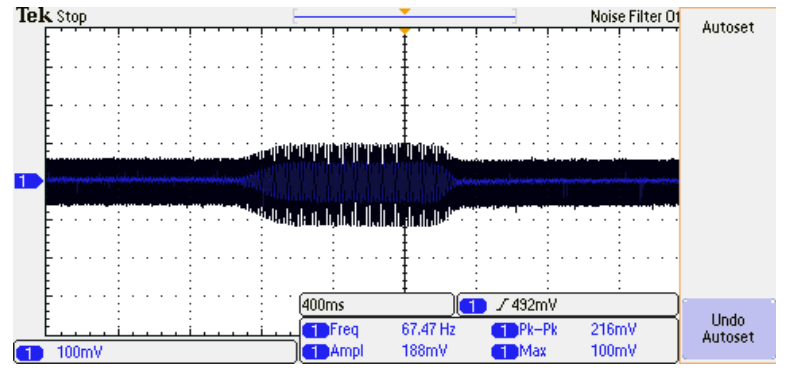

Gambar 12. Sinyal EMG keluaran dari otot kontraksi kuat dengan sudut lengan $90^{\circ}$

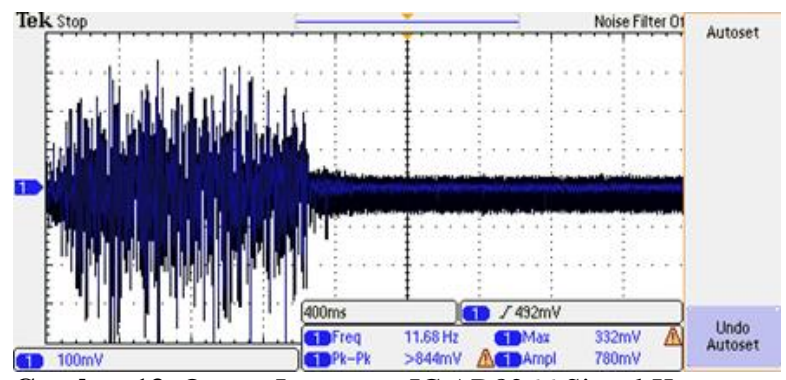

Gambar 13. Output Instrumen IC AD8266 Sinyal Kuat

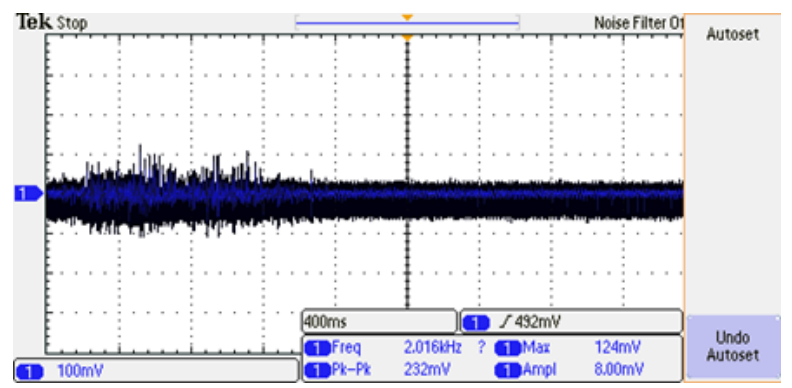

Gambar 14. Output instrumen IC AD 8266 sinyal lemah

Pada pengujian sudut posisi motor yang menggunakan rangkaian sensor rotary encoder yang di letakan diantara piringan mika yang terdapat lubanglubang dengan jumlah 100 lubang yang diartikan sebagai 100 pulsa untuk satu putaran $\left(360^{\circ}\right)$. Berdasarkan hal itu maka besar sudut untuk 1 pulsa adalah $360^{\circ} / 100=3,6^{\circ}$.

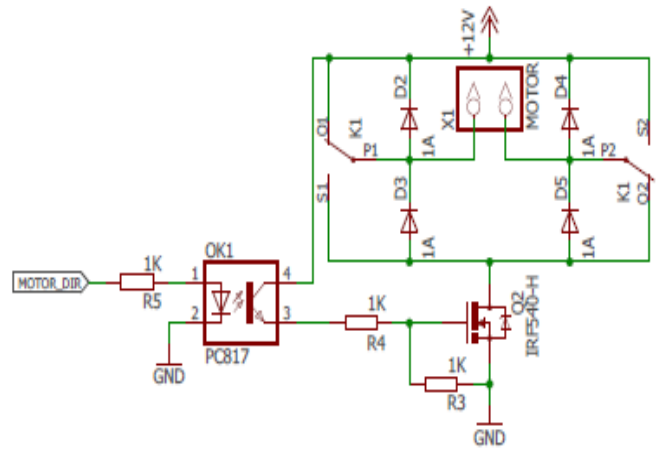

Gambar 15. Skematik rangkaian driver motor
Tabel 3. Hasil pengujian pengatur kecepatan motor

\begin{tabular}{ccc}
\hline Responden & $\begin{array}{c}\text { Setting Speed Alat } \\
\text { (rpm) }\end{array}$ & $\begin{array}{c}\text { Instrumen } \\
\text { Pembanding } \\
\text { (rpm) }\end{array}$ \\
\hline & & $\mathrm{x}$ \\
\hline 1 & 70 & 69 \\
2 & 70 & 70 \\
3 & 70 & 71 \\
4 & 70 & 65 \\
5 & 70 & 69 \\
6 & 70 & 67 \\
7 & 70 & 67 \\
8 & 70 & 67 \\
9 & 70 & 70 \\
10 & 70 & 72 \\
\hline
\end{tabular}

Tabel 4. Hasil pengujian pengatur sudut posisi motor

\begin{tabular}{ccc}
\hline Responden & $\begin{array}{c}\text { Setting Speed Alat } \\
\left({ }^{\circ}\right)\end{array}$ & $\begin{array}{c}\text { Instrumen } \\
\text { Pembanding } \\
\left({ }^{\circ}\right)\end{array}$ \\
\hline & & $\mathbf{X}$ \\
\hline 1 & 45 & 48 \\
2 & 45 & 49 \\
3 & 45 & 42 \\
4 & 45 & 49 \\
5 & 45 & 48 \\
6 & 45 & 42 \\
7 & 45 & 41 \\
8 & 45 & 40 \\
9 & 45 & 41 \\
10 & 45 & 48,5 \\
\hline
\end{tabular}

Analisis uji t satu sampel digunakan dalam penelitian ini untuk mengetahui tingkat kebenaran pengujian, dengan Persamaan 2.

$$
t=\frac{x-\mu}{\frac{s}{w}}
$$

Dimana t merupakan nilai uji $\mathrm{T}$, $\mathrm{x}$ merupakan nilai ratarata hasil ukur, $\mu$ merupakan nilai setting/actual, s merupakan standar deviasi, dan $\mathrm{n}$ merupakan jumlah sampel.

Nilai rata-rata :

$$
\begin{aligned}
& =\frac{69+70+71+65+69+67+67+67+70+72}{10} \\
& =68.7
\end{aligned}
$$

Standar deviasi :

$$
\begin{aligned}
& =\frac{(10) \cdot(23152)-(115600)}{(10) \cdot(9)} \\
& =2.05 \\
& t=\frac{68.7-70}{\frac{2.05}{\sqrt{10}}}=2.1
\end{aligned}
$$




\section{TEKNIK, 40 (3), 2019, 182}

Menggunakan tabel $\mathrm{t}$ pada $\alpha / 2$ dan derajat bebas (degree of freedom) $(\mathrm{df}=\mathrm{n}-1)$. Hasil dari tabel $\mathrm{t}$ diperolah nilai $\mathrm{t}$ tabel adalah 2,1. Berdasarkan tabel $\mathrm{t}$ diketahui $\mathrm{t}(0,05 / 2,10-1)$ adalah 2,2157 , karena nilai $\mathrm{t}$ hitung $<\mathrm{t}$ tabel maka Ho diterima dan Ha ditolak. Dengan demikian, dapat disimpulkan bahwa nilai kecepatan putaran motor adalah 70rpm.

$$
\begin{aligned}
& \text { Nilai Rata }- \text { Rata } \\
& =\frac{48+49+42+49+48+42+41+40+41+48.5}{10} \\
& =44.8
\end{aligned}
$$

Standar deviasi:

$$
\begin{aligned}
& =\frac{(10) \cdot(23152)-(115600)}{(10) \cdot(9)} \\
& =2.9 \\
& \mathrm{t}=\frac{44.8-45}{\frac{2.9}{\sqrt{10}}}=2.26
\end{aligned}
$$

Dengan menggunakan tabel $\mathrm{t}$ pada $\alpha / 2$ dan derajat bebas (degree of freedom) $(\mathrm{df}=\mathrm{n}-1)$. Dengan menggunakan tabel $\mathrm{t}$ diperolah nilai $\mathrm{t}$ tabel adalah 2,262157 . Berdasarkan tabel $t$ diketahui $t(0,05 / 2,10-1)$ adalah 2, 82144, karena nilai t hitung $<\mathrm{t}$ tabel maka Ho diterima dan Ha ditolak. Dapat disimpulkan bahwa nilai sudut putaran motor rata-rata adalah $45^{\circ}$.

Perhitungan kalibrasi kecepatan motor dapat di ketahui dengan persamaan :

$$
\bar{x}=\sum_{i=1}^{n} \frac{x_{i}}{n}
$$

Nilai Rata - Rata :

$\frac{69+70+71+65+69+67+67+67+70+72}{10}=68.7$

Nilai Kesalahan

$=70-68=2$

Kesalahan Relatif

$=\frac{70-68.7}{70} \times 100 \%==2.8 \%$

StandarDeviasi :

$=\underline{(10) \cdot(23152)-(115600)}=2.05$

$$
\text { (10).(9) }
$$

Ketidakpastian Pengukuran :

$$
\begin{aligned}
& =\frac{\text { STDEV }}{\sqrt{n}} \\
& =2.5 / \sqrt{ } 10=0.66
\end{aligned}
$$

Tabel 5. Hasil perhitungan kalibrasi kecepatan

\begin{tabular}{ccccccc}
\hline $\begin{array}{c}\text { Responde } \\
\text { n }\end{array}$ & $\begin{array}{c}\text { Setting } \\
\text { Speed } \\
\text { Akat } \\
\text { (rpm) }\end{array}$ & $\begin{array}{c}\text { Teruku } \\
\text { Rata- } \\
\text { rata }\end{array}$ & $\begin{array}{c}\text { Kesalaha } \\
\mathbf{n}\end{array}$ & $\begin{array}{c}\text { Kesalaha } \\
\mathbf{n} \\
\text { relative } \\
(\%)\end{array}$ & $\begin{array}{c}\text { Kesalaha } \\
\text { n Max } \\
\text { yang } \\
\text { diijinkan }\end{array}$ & $\begin{array}{c}\text { Ketidak } \\
\text { pastian } \\
\text { pengukura } \\
\text { n }\end{array}$ \\
\hline 1 & 70 & 68,7 & 1,3 & 0,019 & 4,6 & 0,66 \\
2 & 70 & 68,7 & 1,3 & 0,019 & 4,6 & 0,66 \\
3 & 70 & 68,7 & 1,3 & 0,019 & 4,6 & 0,66 \\
4 & 70 & 68,7 & 1,3 & 0,019 & 4,6 & 0,66 \\
5 & 70 & 68,7 & 1,3 & 0,019 & 4,6 & 0,66 \\
6 & 70 & 68,7 & 1,3 & 0,019 & 4,6 & 0,66 \\
7 & 70 & 68,7 & 1,3 & 0,019 & 4,6 & 0,66 \\
8 & 70 & 68,7 & 1,3 & 0,019 & 4,6 & 0,66 \\
9 & 70 & 68,7 & 1,3 & 0,019 & 4,6 & 0,66 \\
10 & 70 & 68,7 & 1,3 & 0,019 & 4,6 & 0,66 \\
\hline
\end{tabular}

Perhitungan Kalibrasi sudut posisi motor dapat diketahui dengan persamaan :

Nilai rata-rata :

$=\underline{48+49+42+49+48+42+41+40+41+48.5}=44.8$ 10

\begin{tabular}{|c|c|c|c|c|c|c|}
\hline Responden & $\begin{array}{c}\text { Setting } \\
\text { Settin } \\
\text { g } \\
\text { sudut } \\
\text { alat }\left(^{0}\right)\end{array}$ & $\begin{array}{c}\text { Terukur } \\
\text { Rata- } \\
\text { rata }\end{array}$ & Kesalahan & $\begin{array}{c}\text { Kesalahan } \\
\text { relative } \\
(\%)\end{array}$ & $\begin{array}{l}\text { Kesalahan } \\
\text { Max yang } \\
\text { diijinkan }\end{array}$ & $\begin{array}{c}\text { Ketidak } \\
\text { pastian } \\
\text { pengukuran }\end{array}$ \\
\hline 1 & 45 & 44,85 & 0,15 & 0,3 & 15,2 & 0,66 \\
\hline 2 & 45 & 44,85 & 0,15 & 0,3 & 15,2 & 0,66 \\
\hline 3 & 45 & 44,85 & 0,15 & 0,3 & 15,2 & 0,66 \\
\hline 4 & 45 & 44,85 & 0,15 & 0,3 & 15,2 & 0,66 \\
\hline 5 & 45 & 44,85 & 0,15 & 0,3 & 15,2 & 0,66 \\
\hline 6 & 45 & 44,85 & 0,15 & 0,3 & 15,2 & 0,66 \\
\hline 7 & 45 & 44,85 & 0,15 & 0,3 & 15,2 & 0,66 \\
\hline 8 & 45 & 44,85 & 0,15 & 0,3 & 15,2 & 0,66 \\
\hline 9 & 45 & 44,85 & 0,15 & 0,3 & 15,2 & 0,66 \\
\hline 10 & 45 & 44,85 & 0,15 & 0,3 & 15,2 & 0,66 \\
\hline
\end{tabular}

Nilai kesalahan :

$=45-44.8=0.15$

Kesalahan relatif :

$=\underline{45-44.8} \times 100 \%=0.5 \%$

45

StandarDeviasi :

$=\underline{(10) \cdot(23152)-(115600)}=3.8$

$$
\text { (10).(9) }
$$

Ketidakpastian Pengukuran :

$$
\begin{aligned}
& =\frac{\text { STDEV }}{\sqrt{ } \mathrm{n}} \\
& =3.8 / \sqrt{ } 10 \\
& =1.19
\end{aligned}
$$

Tabel 6. Hasil perhitungan Kalibrasi sudut

Dari data hasil perhitungan maka nilai rata-rata sudut posisi motor/ nilai kebenarannya adalah sebesar $47.3^{\circ}$ dengan nilai kesalahan maximal yang di ijinkan/ nilai toleransinya adalah $\pm 10 \%$, dan pada hasil Kalibrasi kecepatan motor di dapat nilai kebenarannya 68.7 dengan nilai toleransinya $4.6 \mathrm{rpm}$ Sehingga dapat di simpulkan bahwa hasil penunjukan kecepatan putaran motor dengan nilai setting yang diinginkan dari 10 koresponden masih masuk dalam batas nilai toleransi. Dengan demikian ketelitian sistem driver motor DC 


\section{TEKNIK, 40 (3), 2019, 183}

yang berfungsi untuk mengatur gerakan mekanik alat termasuk pada kategori baik karena mendekati nilai titik seting yang di tetapkan.

\section{Kesimpulan}

Rancang bangun menggabungkan perangkat CPM dengan sinyal EMG telah dilakukan. Perangkat mampu melakukan gerakan pasif secara terus menerus sesuai dengan seting yang diinginkan dan berfungsi secara otomatis dengan pengaturan waktu yang diinginkan. Sinyal EMG dideteksi dengan menggunakan electrode dan rangkaian penguat sehingga dapat diaplikasikan sebagai sistem monitoring sinyal otot pasien. Hasil kalibrasi sistem driver motor pada kecepatan motor adalah $68.7 \mathrm{rpm}$ dan sudut posisi motor adalah $44.8^{\circ}$ dengan batas nilai toleransi masing-masing $\pm 5 \%$. Sinyal electromyograph memiliki perbedaan amplitudo yang tidak terlalu besar, yaitu $0,242 \mathrm{mV}$ pada sinyal gerak lengan $45^{\circ}, 0,253$ pada sinyal gerak lengan $90^{\circ}$ dan $0,372 \mathrm{mV}$. Pengembangan tahap berikutnya adalah Perangkat dapat dikembangkan dengan menambah gearbox pada motor dc untuk meningkatkan kekuatan torsi motornya dan menambahkan High Pass Filter untuk meningkatkan kestabilan output sinyal EMG.

\section{Daftar Pustaka}

Nugraha, P. F. (2010). Pengembangan desain CPM (Continuous Passive Motion) elbow sebagai alat orthose aktif bagi pasien pasca operasi tulang siku tangan menggunakan kendali Microcontroller AT 89C51. Diakses dari https://eprints.uns.ac.id/153/

Ho, H., Chen, T. (2006). Hybrid CPM/CAM physiotherapy device by use of active feedback control loop. First International Conference on Innovative Computing, Information and ControlVolume I (ICICIC'06), 146-149.

Belo, J. C. X., Rofii F., Qustoniah, A. (2018). Rancang bangun sistem pemantau kecepatan dan arah angin menggunakan teknologi komunikasi zigbee. Widya Teknika, 26(1), 1-15.

Muscle sensor V3 user manual. (2013, Februari 4).

Nainggolan, E. M., Rusdinar, A., Sunarya, U. (2015). Perancangan dan implementasi tangan robot buatan dengan menggunakan elektromiogram. eProceedings of Engineering, 2(2).

O'Driscoll, S. W., Giori, N. J. (2000). Continuous passive motion (CPM): Theory and principles of clincial application. Journal of rehabilitation research and development, 37(2).

Rajestari, Z., Feizi, N., Taghvaei, S. (2017). Kinematic synthesis and optimization of Continuous Passive Motion mechanisms for knee. 7th International Conference on Modeling, Simulation, and Applied Optimization (ICMSAO), 1-6.

Rattarojpan, J., Umchid, S. (2012). Design and development of touch screen based Continuous Passive Motion device for knee rehabilitation. 4th 2011 Biomedical Engineering International Conference. 237-241.

Rokhana, R. (2009). Identifikasi Sinyal Electromyograph (EMG) Pada Gerak EkstensiFleksi Siku Dengan Metode Konvolusi Dan Jaringan Syaraf Tiruan. Industrial Electronic Seminar. Diakses dari dari http://repo.pens.ac.id/180/

Saputra, A. W., Wardana, P. S., Rokhana, R. (2010). Robot Lengan 3 DOF dengan input sinyal EMG. Final Project. EEPIS.

Setiawidayat, Sabar ., Rudy, Jogijantoro. (2018). Algorithm for the Representation of Parameter Values of Electrocardiogram. Telkomnika,vol.16 no.3 June 2018, ISSN : 1693-6930 DOI: 10.12928/TELKOMNIKA.v16i3.6934

Umchid, S., Taraphongphan, P. (2016). Design and development of a smart continuous passive motion device for knee rehabilitation. 9th Biomedical Engineering International Conference (BMEiCON), 1-5.

Zhao, W. (2018). Rehabilitation Therapeutics of the Neuorogical Training. Beijing: Springer. 